\title{
FOREWORD TO THE GERMAN EDITION
}

In the midst of the turmoil of the Arab Spring, the influential Time Magazine columnist Fareed Zakaria made a remarkable observation. As time went on, the revolutions in Egypt, Tunisia, Libya, and Yemen only seemed to grow more complicated and harder to define. Faced with their failure to produce an unambiguous democratic success, Zakaria asked himself why the Arab nations have what he called an inherent "democracy deficit." By asking the question, he was following in the footsteps of well-known Orientalists like Bernard Lewis, who had already speculated that the deficit was related to the political and cultural development of the Arab world ${ }^{2}$ (and specifically Arab, rather than Islamic; Muslim countries elsewhere, like Indonesia, do have democratic structures). Zakaria pointed out that the deficit is particularly noticeable in the countries that were conquered by Muhammad's Muslim armies before the twelfth century: "Lands that the Arabs controlled in the $12^{\text {th }}$ century remain economically stunted today." ${ }^{3}$ This reference to a historical

\footnotetext{
${ }^{1}$ Fareed Zakaria, "A Region at War with its History," in Time Magazine, 4.16.2012, available online: http://content.time.com/time/magazine/article/ $0,9171,2111248,00 . h t m l$ (as of 08/15/17).

${ }^{2}$ Bernard Lewis, What Went Wrong? Western Impact and Middle Eastern Response (New York: OUP, 2002).

${ }^{3}$ Zakaria refers to a study by the economist Eric Chaney of the historical factors that led to this predicament: "In areas conquered by Arab armies, by contrast, the use of slave armies meant that military power remained concentrated in the hands of the sovereign. This prevented the emergence of a European-style land-
} 
event that occurred over nine hundred years ago is remarkable for several reasons. For one thing, it once again illustrates the West's strong tendency to seek religious or religious-historical explanations for current political phenomena. The high ratio of government spending to GDP in Arab countries is thought to reflect the "historical" influence of the Islamic conquest, but there are plenty of alternative possible explanations. Not least among them is the fact that almost all the Arab nations are postcolonial in structure, and that their governments and ruling classes - in most cases originally installed by the West - have played important roles as nation builders and agents of modernization but are now being re-evaluated by the people. ${ }^{4}$ On the other hand, this religious-historical reasoning may not be completely groundless. The rise of Islam and the Arab conquest of the Roman East seems to have triggered something that left deep marks on the Western consciousness, coloring its perception of, and probably also relationship to, the Orient ever since. However the West's "dismay" is defined or explained, it makes objective analysis of the historical period rather difficult. When we try to understand the historical relationship between the Arabs in Oriens and the Arabian Peninsula and the Romans, in whose "backyard" the new Islamic religion was born, we encounter an interesting phenomenon: the Arabs of the pre-Islamic period are often represented in Western historical writing as an obscure group that only appeared relatively soon before their victory over the Roman Empire, and that previously had had little significance or even reality either inside or outside the empire. The history of the Arabs is all too often invisible, blurred, and unclear: it has been "de-Arabized." For that very reason, however, the success of the Arab conquest and the sudden emergence of the Arabs into world history are hard to explain.

ed aristocracy and the concomitant development of civil society." Eric Chaney, "Democratic Change in the Arab World, Past and Present,' Brookings Papers on Economic Activity, Spring 2012, 363-414, here 382f.

${ }^{4}$ On the role of the ruling class in modernization, see Samuel P. Huntington, Political Order in Changing Societies (Yale: YUP, 1968). 
There are several highly divergent accounts of this phase of Arab history, roughly classifiable into Western and Arab perspectives (this distinction is not meant to be a precise ethnic one; there are Arab and Western scholars in both camps). The "Arab" view is that this period of history was one long, steady development that began three thousand years before Christ in Yemen. The tribes who migrated north from this Arab homeland subsequently founded many civilizations with clear similarities in language and culture. In this view, the Arab conquest of Oriens simply re-revealed an identity that had long been obscured or pushed into the background by Roman and Persian rulers. In the Western account, on the other hand, these migrations were "Semitic," and the tribes who traveled out of southern Arabia or another "proto-Semitic" homeland were the ancestors of a range of different languages and cultures that had little to do with one another. In this view, the Arabs are just one among many Semitic civilizations, and moreover one that came late to the scene and then managed, by taking advantage of "critical moments" and exploiting the momentum of their own religion, to defeat Rome and the Sassanids and to create their own global empire, writing system, culture, and religion. Indeed, some of these achievements (writing, poetry, religion) are even seen as a retroactive "invented tradition" intended to give the new Islamic nation appropriately deep historical roots.

There is a vicious circle at work here. The de-Arabization and deconstruction of Arab history have rendered many historical developments inexplicable, leading some Western scholars to turn to revisionist theories in an attempt to explain them. Arab historians do not share this way of looking at history. The two accounts grow ever further apart, each travelling down its own path. Communication and exchange between the two seems ever more unlikely. And so we find ourselves confronted by the paradox that the Arab element is often given more prominence, and is less "atomized" and deconstructed, in the works of earlier Western scholars than those of modern historians, whose historical perspective, filtered as it is through the lens of numerous sub-disciplines, prevents them from achieving a sufficiently broad and integrative view. 
These two phenomena - the reliance on religion or the history of religion to explain current problems, and the often mysterious and controversial substance of such history - are intimately related. The history of the Arab world is, for a variety of reasons, very important to the West. We suggest that this fact may have had, and indeed has had, a massive influence on the construction and interpretation of that history. The Western attitude may ultimately be rooted in a form of "defensive reaction" or perhaps even a "trauma" caused by the loss of Christianity's original homeland. This study will show how that defensive reaction was able to build on the tendencies of the classical historians, who, in response to periods of Arab dominance within the Roman government and Rome's inability to deal with the increasing autonomy of the Arabs, warned of the dangers of "Orientalization." Their attitude towards the Arabs was one of suspicion and probably also aversion.

Based mainly on Western and Arabic secondary literature, this study seeks to counter the de-Arabization of pre-Islamic Arab history by presenting a more nuanced picture of the historical development of the Arab world. It focuses particularly on the period stretching from the conquest of Arabia by Alexander the Great in 331 B.C., via the reorganization of the Roman province of Oriens by Pompey in 64/63 B.C., up to the Arabs' almost overnight victory over the Romans at the Battle of Yarmūk seven hundred years later, on August 20, 636. A succinct account of the history of the Arabs in the Roman East before the Islamic conquest reveals the long development of the Arab peoples. This study may help draw attention to this period of Arab history. If it also manages to paint a picture of the shared history of Arabs and Romans that can provide an alternative to conventional Orientalist clichés and prejudices, then it will more than have fulfilled its goal. 